\title{
AFFETME: KURAMSAL BİR DEĞERLENDİRME ${ }^{1}$
}

\section{Naciye Güven ${ }^{2}$ Tuğçe Erdem ${ }^{3}$}

\begin{tabular}{|c|c|}
\hline Bilgisi & Özet \\
\hline DOI: 10.35 & \multirow{11}{*}{$\begin{array}{l}\text { Pozitif psikolojiye yönelik ilginin artmasıyla birlikte affetme kavramı üzerinde } \\
\text { yapılan araştırmalar da artış göstermiştir. Affetme kavramının kökenini dini } \\
\text { inançlar oluşturmuş olsa da affetme, zaman geçtikçe farklı disiplinler içerisinde } \\
\text { de kendine yer bulmuştur. Tek bir affetme tanımı oluşturulamamakla birlikte } \\
\text { genel bakış açısıyla affetme kişinin yaşadı̆̆ı negatif deneyimlere yönelik } \\
\text { hissettiği olumsuz duyguları, bilinçli bir çaba ile olumlu hâle çevirmesi olarak } \\
\text { ifade edilebilir. Bu makalede; affetme kavramı, affetme ile sıklıkla karıştırılan } \\
\text { kavramlar, kendini affetme, başkalarını affetme ve durumu affetme, affetme } \\
\text { sürecine yönelik geliştirilen modeller, affetme sürecini kolaylaştıran ve } \\
\text { zorlaştıran etmenler, affetme sürecinde mağdurun ve suçlunun sahip olduğu } \\
\text { kişilik özelliklerinin etkisi, affetmenin taraflara sağladığı faydalar ve affetme ile } \\
\text { ilgili yapılan araştırmalar ele alınmıştır. }\end{array}$} \\
\hline Anahtar Kelimeler & \\
\hline Pozitif Psikoloji & \\
\hline Affetme & \\
\hline Kuram & \\
\hline Gönderim Tarihi: 21.11.2020 & \\
\hline Kabul Tarihi: 04.12.2020 & \\
\hline & \\
\hline & \\
\hline & \\
\hline & \\
\hline
\end{tabular}

\section{FORGIVENESS: A THEORETICAL ASSESSMENT}

Article Info

DOI: 10.35452/caless.2020.31

Keywords

Positive Psychology

Forgiveness

Model

Received: 21.11.2020

Accepted: 04.12.2020

Published: 10.12.2020

Abstract

With the increase of interest in positive psychology, the number of studies on forgiveness as a term increased, too. Although the roots of forgiveness as a term lies under religious beliefs, as time has passed, the term has found its place in other disciplines. In spite of the difficulty in providing only one definition for the term, it can be defined in broad terms as the transformation of the negative feelings that someone has towards unpleasant experiences into positive with conscious effort. In this article, the following is examined; the term 'forgiveness', other terms that are often mistaken for forgiveness, different aspects of forgiveness; forgiving oneself, others and the situation itself, different models that are developed for the process of forgiving, the factors that make the forgiveness process easier or harder, the effects of the personal qualities of the victim and the guilty, the benefits of forgiving for both parties and the research on forgiveness.

APA'ya göre alıntılama: Güven, N. ve Erdem, T. (2020). Affetme: Kuramsal bir değerlendirme. Uluslararası Dil, Eğitim ve Sosyal Bilimlerde Güncel Yaklaşımlar Dergisi (CALESS), 2(2), 578-607.

Cited as APA: Güven, N., \& Erdem, T. (2020). Forgiveness: A theoretical assessment. International Journal of Current Approaches in Language, Education and Social Sciences (CALESS), 2(2), 578-607.

\footnotetext{
${ }^{1}$ Bu çalışma, Kırıkkale Üniversitesi Sosyal Bilimler Enstitüsü, Rehberlik ve Psikolojik Danışmanlık Anabilim Dalında Tuğçe Erdem tarafından yürütülen yüksek lisans tez çalışmasının bir bölümünden oluşmaktadır.

2 (D) Kırıkkale Üniversitesi, Eğitim Bilimleri Bölümü, Türkiye, naciyeozkara@hotmail.com

3 (D) Milli Eğitim Bakanlığı, Türkiye, tugcerdm@gmail.com
} 


\section{Giriş}

Sosyal bir varlık olan insan, en derin bağlılık gereksinimlerini yakın ilişkilerle karşılamaya çalışır. Yakın ilişkilerde ihtiyaçları, özlemleri ve umutları yerine getirmek için kurulan köprü, kişileri birbirine bağlayarak onları başka bir insana karşı savunmasız hâle getirmektedir. Kişinin kendisini savunmasız bırakması iki ucu da keskin olan bir kılıca benzer. Bu kılıç ilişkide herhangi bir kusur meydana çıktığında yaralama veya yaralanma durumunun kaçınılmaz olduğunu ifade eder. Yaralanma durumu meydana geldiğinde duyulan acı kişiyi savunmasız bir hâle getirir. Bu savunmasızlık yaralanan kişide olumsuz duygular (öfke, kızgınlık, hayal kırıklığı) ortaya çıkarır (Fincham, 2000). Kişi olumsuz duyguların kaynağını önlemek ve zararı görmek için geri çekilir. Bu gibi durumlarda intikam alma isteği ile oldukça sık karşılaşılır. Bu noktada kişi ya duyulan acıya ve intikam alma düşüncesine odaklanacaktır ya da affetme düşüncesinin iyileşme metodu olarak kabulünü sağlayacaktır. Affetme, insanları öfkelerinden ve genellikle bilinçsiz öfkenin sonucunda oluşabilecek olumsuz davranışların getireceği suçluluk duygusundan kurtaran bir müdahaledir (McCullough ve Worthington, 1999). Affetme kararma varan kişi olanlara anlam vermeye çalışır. İncinen kişi affetme kararını verirken ilişkiye verdiği önemi, kendini inciten kişinin niyetini ya da geçmişteki davranışlarını ve mevcut problemi, ihlali gözden geçirir (Scobie ve Scobie, 1998). Affetmek, öfke, hayal kırıklığı, intikam gibi olumsuz yıkıcı duyguları omuzlardan atmaktır. Bu süreçte kişi öncelikle kendi yaşadığı acılarla yüzleşir. Bu acıların altından kalkmaya başladığında ise karşısındakine acı verme arzusu da azalır (Akgün, 2016).

$\mathrm{Bu}$ çalışmanın amacı, kişinin hayatının büyük kısmında yer alan sosyal ilişkilerde, kendisiyle ve kontrol edemediği durumlarda yaşadığı olumsuz duyguları olumlu hâle getirdiği affetme kavramını alanyazın ışığında derinlemesine açıklamak ve affetme kavramıyla ilişkili yapılacak araştırmalara destek olmaktır.

Yıkıcı duyguların yerini yapıcı duygulara bırakması ve intikam/öç alma fikirlerinin zihinden uzaklaştırılması şeklinde de ifade edilen affetmenin bireylerin sağlıklarını fizyolojik ve psikolojik olarak etkilediği bilinmektedir (Mameghani, 2017). Toussaint, Williams, Musick ve Everson (2001) kolay affeden bireylerin hastalık belirtilerini daha az sergilediklerini ve affetmenin sağlığı fizyolojik yönde olumlu etkilediğini ortaya çıkarmışlardır. Bununla birlikte affetme bireyin psikolojik sağlığını da olumlu yönde etkilemektedir (Satıcı, 2016). Kişinin yaşamını psikolojik ve fizyolojik yönde etkileyen affetme kavramı üzerine yapılmış bu çalışma Türkçe alanyazındaki boşluğa katkı sağlamak noktasında önem arz etmektedir. 


\section{Kavramsal Olarak Affetme}

1980'li yıllarda affetme teolojik bir kavram olarak görülmekte ve bu sebeple psikoloji içerisinde çok az ilgi görmekteydi (Scobie ve Scobie, 1998). Psikoloji alanyazınına 90 'lı yılların başında girmiş ve bu konu üzerinde yapılan araştırmalar son 20 yılda artışa geçmiştir (McCullough, Worthington ve Rachal, 1997).

Affetme kavramı teoloji ve felsefi alanyazınında kendisine sıklıkla yer edinmiştir (Taysi, 2007). Felsefi modeller affetmeyi erdem ve ahlaki açıdan doğru olanı destekleyen veya çürüten argümanlarla ilgilenmektedir. Bununla birlikte affetme, vicdan kavramı ile denk düşmektedir. Dini modeller ise affetmenin yanı sıra affedilmenin de önemli olduğunu vurgular. İnanan Tanrı tarafından affedilmek için çaba sarf eder ve günlük ilişkilerinde de Tanrı'nın affediciliğinin taklidini uygular. Din, inanan bireyin affetmesini ve intikam duygularından arınmasını telkin eder bu sebeple incinen birey suçluyu affettiğinde dini görevini yerine getirdiğini düşünerek huzur duygusunu tadacaktır (Scobie ve Scobie, 1998). Psikoloji bilimi ise negatif deneyimlere sebep olan durumun, incinen birey üzerinde biraktığı olumsuz etkiye odaklanır. İncitici olay sonrasında mağdur kızıılık, kin gibi olumsuz duygular yaşar ve psikoloji bireyin bu duyguları geride bırakabilmesi ve suçlunun kontrolünden kurtulabilmesi için bir yol sunmaya çalışır. Sunulan yol mağdur bireyin perspektifini değiştirerek suçlu bireye karşı oluşan olumsuz duygular yerine empatiyi ve sevgiyi içeren olumlu duyguların yerleştirilmesi temelinde ilerler. Sonuç olarak affetme, incinme ve zarar görme durumunda bireyin bu duruma karşı duyuşsal, bilişsel ve davranışsal boyut üçlemesinin olumsuzdan olumluya ilerlediği aşamalardan oluşan bir süreçtir (Bugay ve Demir, 2011).

İncinen bireyin affetmesini kolaylaştıracak özür dileme, empati ve ilişki süresi gibi değişkenler söz konusu olsa da affetme bireysel bir süreçtir ve dışarıdan herhangi bir baskı bu süreci etkilememelidir. Kişi incindiği bir durumda kendini engelleyebilir, anlayış gösterebilir ya da sessiz bir şekilde affetme kararına varabilir. Bu tepkilerden hangisinin seçileceğini kişinin kendisinin belirlemesi gerekmektedir. Başkasının zorlaması ile gerçekleşecek bir affetme içi boş bir affetmedir (Scobie ve Scobie, 1998). Kişinin ifadesel anlamda affetmesi fakat duygusal anlamda bu affın sağlanmaması içi boş affetmeye karşılık gelmektedir. Sessiz affetmeye bakıldı̆̆ında ise kişi inciten kişiyi affeder fakat bunu ona iletmez (Adam Karduz, 2019). Baumeister, Exline ve Somner'e (1998) göre affetme durumunda kişilerarası davranışın olması fakat içsel durumun olmaması sahte affetmeyi, kişiler arası davranışın olmaması fakat içsel durumun olması sessiz affetmeyi, kişilerarası davranışın ve içsel durumun olması tam affetmeyi, kişilerarası davranışın ve içsel durumun olmaması ise affetmemeyi 
işaret etmektedir. Gerçek affetme, incinen bireyin haksızlığa uğramasını ve istekli bir şekilde, zorlama olmadan hakkı olarak gördüğü intikam davranışından vazgeçerek merhamet duygusuyla davranışlarına yön vermesi şeklinde gerçekleşir (Enright ve Coyle, 1998).

Kendini Affetme: Affetme kavramı araştırmaların genelinde kişiler arası bir süreç olarak ele alınmış, kendini affetme kavramı üzerine fazla yoğunlaşılmamıştır (Arslan, 2019). Hall ve Fincham (2005), kendini affetme kavramını kişinin kendi hatasıyla yüzleşerek kendisini affedemediği olaydan uzaklaşarak olumlu duygular hissetmeye motive olması ve kendisinden öç alma isteğinin azalması ile kendisine yardımcı olmadaki arzusunun artması şeklinde tanımlamıştır. Kendini affetme iki şekilde karşımıza çıkmaktadır. Bunun ilki kişinin kendisine verdiği zarar sebebiyle kendisini affetmesi yönünde olurken bir diğer şekli ise bireyin başkasında oluşturduğu incinme sebebiyle kendisini affetmesidir (Besim, 2017). Bir başka ifade ile kişinin kendine yönelik cezalandırma arzusunun azalması kendini affetme davranışını işaret eder. Kendini affetme de genel affetme gibi bilinçli bir çaba ile gerçekleşmektedir (Enright vd., 1996). Kişinin kendini affetmesi, hatayı kabullenmesi ve sorumluluğunu üzerine almasıyla gerçekleşir (Taysi, 2007). Kişiliğin yargılayıcı boyutu öncelikle işe kişinin kendisi ile başlar. Kişi yaptığı davranışlar, kullandığ kelimeler hatta bazı zamanlarda aklından geçen düşünceler için bile kendine kızar ve acımasız yaklaşır. Bu acımasızlık bireyin benlik kavramına da önemli darbeler vurabilir (Besim, 2017). Kendi hataları sebebiyle oluşan anksiyete, kızgınlık, gerginlik, öfke, pişmanlık vb. duyguları yaşayan birey kendini cezalandırma yolunu çoğu zaman zihninden geçirir. Farklı bir yönden bakacak olursak kişinin kendine karşı duyduğu olumsuz ve yıkıcı duyguları devam ettirmesi de kendini cezalandırma yöntemi olarak görülebilir. Worthington'a (2006) göre kişinin kendine duyduğu olumsuz duygularıyla başa çıkması ve kendini affetmesi başkalarına ilişkin duygularıyla başa çıkmasından daha zordur. Bu sebeple kişinin kendini affedememesi, başkalarını ya da durumu affedememesinde çok daha yorucu ve yaralayıcı bir süreçtir. Kişiler arası ilişkilerde affedilemeyen kişiden uzaklaşma söz konusu olurken kendini affetmeme durumunda oluşacak kendinden uzaklaşma durumu büyük hasarlara sebebiyet verebilmektedir (Arslan, 2019).

Başkalarını ve durumu affetmede hata kişinin kendisinde değilken kendini affetmede hata kişinin kendisindedir. Bu nokta başkalarını ve durumu affetme süreçlerinde empatinin kolaylaştırıcı olduğunu fakat kendini affetme boyutunda empatinin engelleyici etkisi olduğunu göstermektedir. Kendini affetme kişinin hatalarını görmezden gelmesi olarak tanımlanmamalıdır (Kaya, 2015). Bu şekilde bir 
tanım yapılması durumunda kendini affetme ve narsisizm arasında bir fark görülmeyecektir. Fakat narsisizm kendini diğerlerinden üstün görme ve tüm olaylara benmerkezci bakma odaklıyken affetme sevgi odaklıdır (Enright vd., 1996).

Başkalarını/Kişiler Arası Affetme: Affetme üzerine yapılan tanımlamaların çoğunluğu kişiler arası affetme üzerinedir (Arslan, 2019). Başkalarını affetme haksız bir davranışla karşılaştığında oluşan kızgınlık, öfke, hayal kırıklığı gibi duygular hissetmemeye çalışması olarak tanımlanabilmektedir (Fincham, 2000). Karşısındaki kişiye karşı hissedilen olumsuz ve yıkıcı duygular kişiler arası ilişkilerin yıpranmasına, incinen kişinin inciten kişiden uzaklaşmasına sebep olarak ilişkide bir gerginliğe ve bozulmaya temel oluşturur (Adam Karduz, 2019). Kişinin karşısındaki kişiyi affetmesi ilişkinin doğasına dönmesini sağlayarak kişinin psikolojik dengesinin de eski hâlini bulmasına yardımcı olur (McCullough vd., 1997). İnsanlar birbirlerini üzme eğilimine sahipken aynı zamanda birbirini affetme güdüsünü de barındırırlar (Fincham, 2000). Bu noktada kişiler arası affetme kavramını etkileyen birçok değişken bulunmaktadır. İncinen kişinin inciten kişi ile ilişkisinin kalitesi, süresi, verilen emek miktarı, inciten kişinin pişmanlık hissetmesi, hatanın niteliği bu etmenlerden bazılarıdır (Arslan, 2019; Aslı ve Demir, 2011; Şamatacı, 2013). Kişiler arası affetme kendiliğinden gelişmesi gereken bir süreçtir ve bu sürece dışarıdan herhangi birinin müdahalesi söz konusu olmamalıdır. Aynı zamanda kişilerarası affetme incinen kişinin bilinçli çabasını gerektirmektedir. Bu çaba verilirken inciten kişinin aynı davranışlara devam etmesi süreci zorlaştıracaktır. Bu noktada inciten kişinin incinen kişinin olumsuz duygularının artmasına sebep olacak davranışlar sergilememesi affetme sürecini kolaylaştıracaktır (Besim, 2017).

Durumu/Olayı Affetme: Durumu affetme kavramı kişinin kontrol edemediği deprem, sel, heyelan, yangın vb. doğal afetleri, hastalıkları affetmesi şeklinde tanımlanmaktadır. Kontrol dışında gelişen olaylar kişiye çaresizlik, kızgınlık, öfke, acı vb. olumsuz duygular hissettirerek kişiyi olumlu duygulardan uzaklaştırır. Oluşan olumsuz duygular kişiye zarar verir. Bu sebepledir ki olumsuza evrilen bu duyguları nötr hâle ya da eskisi gibi olumlu hâle getirip olayları affetmek kişinin psikolojik sağlığını olumlu etkileyecektir (Thompson, Snyder, Hoffman, Michael, Rasmussen ve Billings, 2005). Beklenmeyen anda ve kontrol dışında gerçekleşen olaylar çaresizlik duygularını beraberinde getirir. Kişinin sağlı̆̆1 yerindeyken geçireceği bir trafik kazası insanın sağlamlık algısını sarsabilmektedir. Trafik kazası sebebiyle kişi negatif düşüncelere, olumsuz duygulara ya da işlev bozukluklarına sahip olabilir. Birey sürekli kendisine "Bu durum hayatımı altüst etti.", "Neden ben?" gibi düşünceler söyleyebilir. Böyle bir durumda kişinin trafik kazasına karşı 
oluşturduğu olumsuz duygu ve davranışını değiştirerek önce nötr hâle sonrasında ise olumlu hâle dönüştürmesi durumu affetme boyutuna örnek olarak gösterilebilir (Besim, 2017).

\section{Affetme ile Karıştırılan Kavramlar}

Affetme ile benzeyen özelliklere sahip fakat affetmekten farklı olan kavramları birbirinden ayırmak önemlidir. Affetme ile uzlaşma, unutma, haklı çıkarma, göz yumma, mazur görme gibi kavramlar aynı değildir (Hall ve Fincham, 2005; Scobie ve Scobie, 1998).

Sahte Affedicilik, mağdur bireyin hatalı bireyin hissettiği suçluluk duygusundan yararlanarak güç elde etmesi ve bu gücü sürdürme çabasıdır (Çolak, 2014). Mağdur, affettiğini ifade etse de incinmeye sebep olan olayı hatırlatma eğilimindedir ve suçlunun kendisine minnettar olmasını arzu etmektedir. Bu durumda da affetmenin gerçekleştiğini ifade etmek zordur (Enright ve Coyle, 1998).

Göz yumma, haksızlığa uğrayan kişinin olayı görmezden gelerek herhangi bir hasara uğramadığını düşünmesi şeklinde ortaya çıkar (Taysi, 2007). Bu düşünce içerisinde olan birey affetmeyi gerektirecek herhangi bir durum olmadığını ifade etmektedir (Satıc1, 2016). Göz yumma kavramında iki taraf da haksızlığa maruz kalmış ve incinmiş birisini görmediği için hatanın üzeri kapatılır ve inkâr yolu seçilir (Enright, 2001).

Mazur görme ile göz yumma arasındaki fark, bireyin haksızlığa sebep olan davranışın bilincinde olması şeklinde ifade edilebilir (Satıcı, 2016). Mazur görmede mağdur birey hatalı davranışın farkındadır fakat suçlu bireyin haklı bir sebebi olduğuna inanmaktadır (Çolak, 2014). Mazur görme suçluya bir neden vererek hata üzerindeki sorumluluğunu kaldırır. Ortada hataya yönelik sorumluluk olmamasından kaynaklı herhangi bir affetme de söz konusu olmaz. Mazur görmenin geçerli bir sebep olmadan yapılmasının mağdurun ileride benzer bir haksızlığa maruz kalma ihtimalini ve suçlunun da benzer hataları yapma sıklığını artıracağı düşünülmektedir (Baskin ve Enright, 2004).

Hakkını arama; mağdur bireyin hatalı bireyden af dilemesini, suçlu hissetmesini, pişmanlık içerisinde olmasını dilemesidir. Bu istek hatalı davranışın geride bırakılmasını kolaylaştırıcı bir etkiye sahip olsa da suçlu bu istekleri gerçekleştirdiğinde incinen birey kırgınlığı devam ettirerek taleplerini yükseltir. Bu sebeple hakkını arama ile affetme birbirinden farklı kavramlardır (Adam Karduz, 2019). 
Uzlaşma, devam eden bir ilişki sırasında gerçekleşen hatanın ardından bireylerin ilişkiye devam etme kararı almasıdır. Hatalı bireyi suçlamayı sona erdirmek için iç karar olan affetme ile iki taraf arasında gerçekleşen uzlaşma birbiriyle aynı kavramlar değildir (Scobie ve Scobie, 1998). Uzlaşmada taraflar ilişkiyi iyileştirmek için üzerine düşeni yapmak durumundadırlar. Affetme ile en çok karıştırılan kavram olan uzlaşmada affetme gerçekleşmek zorunda değildir. Başka bir ifade ile affeden birey uzlaşmak zorunda olmadığı gibi uzlaşan bireyin de affetmeyi seçmediği durumlar gözlenebilmektedir (Satıc1, 2016). Uzlaşma ve affetme birbiriyle birlikte gerçekleşmek zorunda değildir. Bazı durumlarda incinen birey olumsuz duygularını geride bırakıp affederken, suçlu bireyin hatalı davranışı tekrar gerçekleştireceği düşüncesi içerisinde olabilir (Enright ve Coyle, 1998). Bu düşünce, birey sebebiyle suçluya olan güvenini kaybederek uzlaşma yolunu seçmeyebilir (Wade ve Worthington, 2003).

Yüzleşme, mağdur ile suçlu bireyin incitici davranış sonrasında bir araya geldiği, mağdurun yaşadığı olumsuz duygulardan bahsettiği, suçlunun ise hatasını kabul ettiği, ön yargısız ve şüphenin dâhil olmadığı bir durumdur. Fakat mağdur ile suçlunun yüzleşme davranışını gerçekleştirmesi kimi zaman ilişkide hasara sebep olur. Bu nedenle yüzleşme affetme sayılmaz (Adam Karduz, 2019).

Unutma, mağdur bireyin incinmeye neden olan davranışı belleğinden uzaklaştırması, bastırması şeklinde tanımlanabilir (Satıcı, 2016). Affetme geçmişte meydana gelmiş incitici olayın verdiği acıyı iyileştirmekte yatar (Baskin ve Enright, 2004). Unutma incinmeye sebep olan davranış affedildiğinde bile gerçekleşmeyebilir (Adam Karduz, 2019). Unutmanın, hatalı davranışın mağdur üzerinde oluşturduğu negatif duyguları bastırmasına odaklandığından, incinen birey için sağlıklı bir durum olmadı̆̆ ifade edilmektedir (Scobie ve Scobie, 1998).

\section{Affetme Modelleri}

Pozitif psikoloji kavramlarından affetmeye olan ilginin artması bazı araştırmacıların da kuramsal modeller sunmasını sağlamıştır. Her model affetme üzerinde kendi bakış açısıyla ilerlese de bazı ortak noktalar barındırmaktadırlar (Walker ve Gorsuch, 2002). Bu modellerin en büyük ortak noktası, affetmenin aslında mağdurun kendi psikolojik iyi oluşu için yararlı olduğu üzerinde yoğunlaşmalarıdır (Bugay ve Demir, 2012).

\section{Enright Affetme Süreç Modeli}

$\mathrm{Bu}$ model affetmenin bir süreç ve bu sürecin içerisinde kişinin gerçekleştirilmesi beklenen 20 basamak ve 4 evre olduğu görüşünü savunur (Enright vd., 1996). 
Enright'ın (1996) oluşturduğu süreç modeli başkalarını ve kendini affetme boyutları için oluşturulmuş olsa da bu iki boyutta da aynı basamaklardan ve evrelerden geçilmesi gerektiğinden iki alt boyut şeklinde değil tek boyut olarak ele alınmıştır. Süreç Modeli içerisinde yer alan evreler ise keşfetme, karar verme, çalışma ve derinleştirme şeklindedir. Süreç Modelinde yer alan evrelere yönelik bilgiler aşağıda özetlenmiştir.

Keşfetme Evresi: Açı̆̆a çıkma veya ortaya çıkma şeklinde de ifade edilen bu evre aslında bir farkındalık evresidir (Satıcı, 2016). Mevcut olay ve hatanın bireysel ve sosyal olarak ne ifade ettiği düşünülmektedir. Bununla birlikte bireyin kullandığ 1 savunma mekanizmaları bu evrede önemsenir. Bu önemsenmenin sebebi, kullanılan mekanizmaların, hatanın kişinin hayatı için önemini yordamada kilit taşı olmasıdır (Asıc1, 2019). Kisacası, bu evrede olumsuz duygulara sebep olan durum incelenir ve kişi, oluşan tüm etkilere yönelik bilinçlenir. Dolayısıyla bu süreç duygusal düzlemde kişi için acı verici bir deneyim olabilir (Enright vd., 1996).

Karar Verme Evresi: Hata, açığa çıkma evresinde tanımlandıktan sonra karar verme evresinde affetme üzerine düşünülür. Affetmenin sağlayacağı yarar sorgulanır. Kişi kendisini yahut başkasını affetmeye karar verdiğinden dolayı bilişsel bir süreç geçirir (Kaya, 2015). Bu evre önemi en yüksek evre olarak kabul edilmektedir (Satıcı, 2016). Keşfetme evresinde kullanıldığından bahsedilen savunma mekanizmalarının kişinin oluşan olumsuz sonuçla baş etmesinde yeterli olmadığı fark edilir (Gündüz, 2014). Bu evrede birey önceden var olmayan bir içgörü edinmek için çaba sarf eder. Karar verme evresinin sonunda affetme tam manasıyla gerçekleşmemiş olsa bile bireyin intikam duygusunun bir kısmı azalabilir (Enright vd., 1996).

Çalışma Evresi: Bu evrenin temel mantığı herkesin insan olduğunun farkına varılması ve bakış açısının değiştirilmesidir (Satıcı, 2016). Yapılan hatalar kişinin zarar görmesine sebep olsa da bu hatayı yapan kişinin (bu gerek bireyin kendisi olsun yahut başkası olsun fark etmeden) insani ve hata yapmaya eğilimli yönünü görmeye çalışmak bu evrenin vazgeçilmez bir parçasıdır (Şamatacı, 2013). Bir başka ifade ile çalışma evresinde birey empatik bir yaklaşım takınır. Karar verme evresinin sonucunda oluşan bilişsel süreç duygusal anlamda dönüşümlere doğru ilerler (Enright vd., 1996). Aynı zamanda çalışma evresi bireyin yaşadı̆̆ı olumsuz duyguları kabullenmesi gerektiğinin bilincine vardığı ve bu duyguları içselleştirdiği bir evredir (Gündüz, 2014).

Derinleştirme Evresi: Bazı kaynaklarda sonuç verme şeklinde de ifade edilen bu evrede hataya karşı kazanılmış farklı bir bakış açısıyla, hatanın oluşturma ihtimali olan kırgınlık, öfke benzeri negatif duygulardan isteyerek, bilinçli bir şekilde 
uzaklaşılır. Bu duyguların yerine telafi edici davranışlar getirilmeye çalışılır (Asıcı, 2019). Çalışma evresinde geliştirilen içgörü ile birlikte birey kendine birtakım sorular yöneltir (Kaya, 2015). Bu soruların içeriği ise kişinin geçmiş yaşantıları içerisinde başkası tarafından affedilme durumu olup olmadığı ve eğer varsa bunu ne şekilde tecrübe ettiği yönündedir (Enright vd., 1996). Bu evrenin sonunda zarar gören birey zarara sebebiyet veren kişiyi anlar, empatik bir şekilde yaklaşır ve affetmeyi tam anlamıyla içselleştirerek duygusal bir rahatlama yaşar. Bu süreç sonucunda birey affetmeyi seçerek psikolojik olarak iyileşir ve kendi içinde ilerleme kaydeder (Satıcı, 2016).

\section{Hargrave'nin Affetme Modeli}

Aile üyeleri arasındaki ilişkilerde affetme temelinde oluşturulan bu modelde Hargrave (2001), olumsuz duygulara sebebiyet veren ve zarar verici olan durumun sebebini ilişkiler arasında sağlanamaması üzerine oluşan güven kaybı olarak işaret etmiştir (Hargrave ve Sells, 1997). Başka bir ifade ile hasara uğramış birey, hasarın sebebi olana yönelik kontrol edemediği kin ve öfke hisleriyle birlikte bu kişiyle arasında sağlıklı ve güven dolu bir ilişki sürdüremeyeceği düşüncesinin beraberinde getirdiği suçluluk ve utanç duyguları içerisindedir (Şamatacı, 2013). Bununla beraber mağdur birey geleceğinde de benzer hasarı yaşayabileceği ihtimalini göz önünde bulundurarak davranışlarını kontrol altında tutmak için çaba sarf edebilmektedir. Bu noktadan hareketle Hargrave affetmenin tanımını bireyin yaşadığı hasar verici davranışa rağmen suçlu kişiyle ilişkisinde güvenin yeniden sağlanması ve böylece hasar gören ile hasara sebep olan kişinin incitici davranışı üzerinde tartışarak ilişkilerini ileriye taşımaları şeklinde oluşturmuştur (Hargrave ve Sells, 1997).

Hargrave'nin affetme modeli iki kategori ve dört istasyon üzerine oturtulmuştur. $\mathrm{Bu}$ kategoriler birbiri ile sürekli etkileşim içerisinde bulunan aklama ve affetmedir. Aklama kategorisi, içgörü ve anlayış istasyonuna sahipken affetme kategorisi içerisinde telafi için olanak verme ve açı affetme istasyonlarını barındırır (Hargrave ve Sells, 1997).

Alanyazında kurtarma olarak da bahsi geçen aklama kategorisinde hasar gören aile üyesi, hasara sebebiyet veren aile üyesine yönelik empatik bir anlayış geliştirerek ortaya çıkan olumsuz duruma yönelik içgörü sahibi olacağ 1 içsel bir yolculuk yaşar (Kaya, 2015). Kazanılan içgörü aklama kategorisinin ilk istasyonudur. İçgörünün gelişmesinin ardından gelen anlayış istasyonu, hataya sebep olan kişinin omuzlarındaki ağır yükü almaya yönelik davranışları barındırır (Sells ve Hargrave, 1998). Suçlu kişiye gösterilen anlayış onun hatalı davranıştaki sorumluluğunu 
ortadan kaldırmaz. Sadece hataya sebep olan kişinin niyetine dikkat edilerek aslında suçlu kişinin de yanılma eğilimine sahip olduğu kabullenilir (Hargrave, 2001).

Bir diğer kategori olan affetme, bazı kaynaklarda onarma olarak da geçmektedir (Sells ve Hargrave, 1998). Affetme kategorisinde mağdur, hasara sebebiyet veren kişiye hatalarını telafi etmesi için birtakım fırsatlar verir (Asıcı, 2013). Onarmanın ilk adımı telafi için olanaklar verme aşıldıktan sonra hasar gören birey ile incitici davranışı gerçekleştiren suçlu birey tartışır, karşılıklı olarak iki birey gelecekleri için anlaşma yolunda ilerler (Hargrave, 2001). Model geliştirilirken aklama ve affetme kategorilerinin de içgörü, anlayış, telafi için olanak verme ve açı affetme istasyonlarının da farklı ilişki dinamiklerinde farklı zamanlarda meydana gelebileceği, bu sebeple de bu istasyonların ve kategorilerin gerçekleştirilmesi gereken sıralı bir evre şeklinde değerlendirilmemesi gerektiği vurgulanmıştır (Hargrave ve Sells, 1997). İstasyonlar arası ilişki dalgalı, geçirgen bir şekilde karşımıza çıkabilmektedir (Kaya, 2015).

\section{Kendini Affetme Modeli}

Affetme üzerine geliştirilen modellerin birçoğu incinen bireyin penceresinden bakarken, suçlunun bakış açısına pek fazla odaklanılmamıştır (Worthington, 2006). Kendini affetme modelinde ise diğer modellerde odaktan uzak olan suçlunun penceresi yer alır (Hargrave, 2001; McCullough, 2001). Hall ve Fincham (2005) affetmenin duyuşsal, bilişsel ve davranışsal boyutların etkisi altında ilerleyen bir süreç olduğunu kabul etmişlerdir. Affetmeyi etkileyen duyuşsal belirleyiciler suçluluk ve utanç olarak karşımıza çıkarken hataya sebep olan bireyin kendine karşı bu duyguları hissetmesi kendini affetmesi üzerinde engelleyici rol oynar (Oral, 2016). Hataya yönelik olan yüklemeler, kendini affetmeyi etkileyen bilişsel belirleyiciler olarak karşımıza çıkar. Yüklemeler dışsal, istikrarsız bir yol izlediğinde kendini affetme daha kolay olacaktır (Asıc1, 2013). Model içerisinde affetme üzerindeki son etki ise incinme durumuna yönelik belirleyicilerdir ve bu belirleyiciler davranışsal boyuta dâhil edilebilmektedir. İncinmeye yönelik belirleyiciler incinen kişiden af dileme, uzlaşmaya yönelik davranışlar içerisinde bulunma, incinme düzeyi olarak ifade edilebilir. Kendini affetme ile suçluluk duyguları ve incinmenin şiddeti arasındaki ilişki negatif yöndeyken, af dileme ile arasındaki ilişki pozitif yöndedir (Hall ve Fincham, 2008). Kendini affetme, bireyin kendisinde sebep olduğu hasarın ardından kendini affetmesi ve başkasında sebep olduğu hasar ardından kendini affetmesi olarak iki şekilde gerçekleşebilir (Hall ve Fincham, 2005).

Son olarak ilgili alanyazına bakıldığında kendini affetme ile başkalarını affetme arasında birtakım farklar bulunmaktadır. Kendini affetmede birey davranış, duygu 
ve düşünce olarak hatayı ele alırken, başkasını affetme davranışsal olarak kendini göstermektedir. Empati, olumlu bir duygu olarak kişiler arası affetmeyi kolaylaştırıcı etkiye sahipken, kendini affetmede zorlaştırıcı bir etmen olarak karşımıza çıkmaktadır. Kişi neden olduğu hasarların ardından kendini affedemezse meydana gelecek sonuçlar kişiler arası affetme başarılamadığında oluşacak sonuçlardan çok daha kötüdür (Taysi, 2007).

\section{Psikodinamik Model}

Affetme, psikodinamik yaklaşım içerisinde ilgiyle yaklaşılan bir kavram olmamıştır (Kaya, 2015). Bu durumun sebepleri arasında affetme davranışının içsel kökenlerinin belirsiz oluşu, çoğunlukla kişiler arası ilişkilere dayanması ve kimi zaman da affetme davranışını gerçekleştiren bireylerin incitici davranış sonucunda meydana gelen negatif duyguları bastırma yolunu seçmesi gösterilebilir. Affetme kavramının dinî alanyazında temellendirilmesi ve araştırılması da bu nedenler arasında yer alabilmektedir (Hortwitz, 2005).

Psikodinamik modelde affetme davranışının gelişimi bebekliğe dayanmakta ve Nesne İlişkileri Kuramı ile beraber ele alınmaktadır (Çardak, 2014). Anne, bebeğe bazı durumlarda kızsa dahi bebeğin ihtiyaçları doğrultusunda kendisini kullanmasına müsaade etmekte ve bebeğe karşı bağışlayıcı davranışlar içerisine girmektedir ki bu durum da bağışlamayı öğrenmesi için bebeğe fırsat sağlar (Taysi, 2007). Nesne ilişkileri kuramı anne ve bebeğin birbirlerine karşı olan duygularında sevginin de nefretin de olduğunu savunur. Bebek saldırganlığını da sevgisini de anneye ve memeye yöneltir. Memeyle olan bu değişken ilişki bebekliğin ilk altı ayını kapsamakta ve paranoid-şizoid pozisyon ismiyle anılmaktadır. Bu pozisyonda bebek, anneyi ihtiyaçlarını yerine getirirken yeterli gördüğünde "iyi anne", ihtiyaçlarını yerine getirmede yetersiz gördüğünde ise "kötü anne" şeklinde idrak eder. Altı aylık sürecin ardından bebeğin imgesindeki iyi ve kötü anne birleşir, zıtlıklar bütün olarak algılanır ve böylelikle depresif pozisyona adım atılır (Murdock, 2012). Depresif pozisyonda çocuk engellemeler sebebiyle anneyi affetme için çaba sarf ederken bir yandan da hataları sebebiyle anneden affetme talep etmektedir (Goldgarb, 2005). Bu çaba ve talep içerisinde olan çocuk affetmeyi öğrenmektedir (Asic1, 2013).

Pingleton psikodinamik yaklaşım temelinde incinmenin bireyin benliğinin narsistik kısımlarında hasara sebebiyet verdiğini ve bu hasarın bireyde kendisinin de her birey gibi hasara açık ve incinebilir, diğer bireylerin saygısına ve sevgisine muhtaç olduğu farkındalığını oluşturarak her durumu kontrolü altında tutamayacağını 
kabullenmesini sağladığını ifade etmektedir. Bir başka ifade ile incinme ve affetme durumu bireyde özel olduğuna yönelik inanışları sarsar (aktaran Bowman, 2003). Psikodinamik model, affetmenin temelinde incinen bireyin öfke, saldırganlık, kızgınlık benzeri negatif duygularından vazgeçmesi ve gitmeye izin verme yeteneğinin kazanılması olduğunu savunur. Terapide ise bu temel üzerinde durularak bakış açısı değiştirilmeye çalışılır (Scobie ve Scobie, 1998).

\section{Bütünleştirilmiş Affetme Modeli}

Scobie ve Scobie (1998), alanyazında yer alan ve affetme yapısının farklı yönlerine odaklanan dört modeli inceleyerek bu modellerin entegrasyonuna dayanan bütünleştirilmiş affetme modelini ortaya çıkarmışlardır. İlk model hatalı davranışın sebep olduğu kaygı, öfke benzeri olumsuz duyguların ortadan kaldırılmasının affedicinin sağlığına sunduğu yararı incelemiştir. İkinci model kızgınlığın üstesinden gelerek doğru ve yanlışın ayırdına varılmasının gerekli olduğu felsefi modeldir. Üçüncü model affetmeyi dini hayat üzerinden ele alırken son model olan prososyal model, kişiler arası ilişkileri düzeltmek için özgeci davranışlara odaklanır.

Dünyayı ve kişiler arası etkileşim deneyimlerini anlamak insan olmanın bir parçasıdır. İnsan birçok durumda çoğunlukla farkına varmadan olayı etiketler. Bu olaya vereceği tepkiye, duygularında olumlu mu yoksa olumsuz mu etkiye sebep olduğuna karar verir (Kaya, 2015). Oluşturulan model ise algılanan olayın olumsuz olduğu durumlar üzerine temellendirilmiştir. Bunun sebebi ise olumsuz olarak kategorize edilen olayların affetme stratejisi gerektireceği düşüncesidir. Olumsuz olarak kategorize edilen olaylar önemsizden şiddetliye doğru uzanan dört ihlal düzeyi ile ortaya çıkmaktadır (Scobie ve Scobie, 1998).

Özür-Otomatik olarak adlandırılan ilk seviyede suçlu kişi mağdur kişinin kişisel alanına yanlışlıkla dâhil olmuştur. Bu seviyedeki olay bireyler arasında ilişki varsa bu ilişkinin kesintiye ve dişsal veya içsel bir hasara uğramasına sebebiyet vermez. Hata yapan kişi bunu yanlışlıkla yaptığından dolayı özür otomatik olarak dilenir ve otomatik olarak kabul edilir (Asıc1, 2013).

Özür-Bağımlı olarak adlandırılan ikinci seviyede hatanın algılanan ciddiyeti biraz artmıştır (Asıc1, 2013). Mağdur bu seviyede suçlunun eylemi ve niyeti arasında ayrım yapacaktır. Bu seviyede hasar orta seviyededir ve genellikle uzun vadeli sonuçlar gözlenmemektedir. Bu seviyede özür, ilk seviyedekinden daha önemli bir pozisyondadır. Mağdur, hatanın kaza olduğu, istenmeden yapıldığı sonucuna varırsa ve ikna edici bir özür dilenmişse konu kapatılmaktadır. Fakat özrün 
samimiyetsiz sunulduğuna karar verilirse, hata tekrarlanırsa olay daha büyük bir önem taşımaya başlar (Scobie ve Scobie, 1998).

Üçüncü seviye olan affetmede, zarar verici olay daha şiddetli ve psikolojik olarak daha aşağılayıcıdır. Hatanın doğasını belirleyen mağdurun zarar algısıdır. Mağdur hak ettiği saygıyı göremediği için yaralanırken, bu hatanın kendilik değerine yönelttiği saldırıya karşı kendini savunma eğilimine girer. Aynı isimle adlandırılan dördüncü seviye ile üçüncü seviye arasındaki ayrım, artan psikolojik ciddiyete dayanmaktadır. Dördüncü seviyede hata, mağdurun benlik saygısına zarar vererek kendisine yönelik algısının değişmesine sebebiyet verir. Dördüncü seviyede yer alan ihlaller bazı durumlarda çok şiddetli bir hâl almaktadır ki bireyin hasarın şiddetinden kurtulmasını sağlamak için terapi gerekir (Scobie ve Scobie, 1998).

Zaman kavramına önem veren bu modele göre, ilk iki seviyede gerçekleşen olayın unutulması üçüncü ve dördüncü seviyedeki olayın ve hasarın unutulmasından kısa sürecektir (Scobie ve Scobie, 1998). Olumsuz olay gerçekleştikten, hangi seviyede olduğu değerlendirildikten sonra incinen bireyin nasıl tepki vereceğine karar vermesi gerekecektir. Hasarın az olduğu birinci ve ikinci seviyede baş etmek daha kolayken, üçüncü ve dördüncü seviyede daha zordur (Asıc1, 2013). Bütünleştirilmiş affetme modelinde inkâr, tekrar yorumlama, intikam arzusu, sahte affetme, affetme şeklinde birtakım tepki stratejileri belirlenmiştir. Bu tepki stratejilerinden affetme haricinde hiçbiri hasarın onarılmasında, problemli durumun çözümlenmesinde yardımcı olmamaktadır (Kaya, 2015).

\section{Affetmenin Sosyal Psikolojik Belirleyicileri Modeli}

Affetmeyi motivasyonel bir süreç olduğu ve prososyal yani olumlu sosyal davranışlar temeline oturtan McCullough (2000), affetmeyi zarara maruz kalan bireyin davranışlarında meydana gelen olumlu sosyal motivasyonel ilerlemeler şeklinde tanımlamıştır (Mccullough, 2001). Model iki olumsuz duyuş ve iki güdü üzerine şekillenmiştir. Bu olumsuz duyuşlar incinme ve öfke iken iki güdü ise kaçınma ve intikam alma isteğidir (Şamatacı, 2013). Zarar veren bir davranışla karşı karşıya kalan birey incinir, incinme duygusunun etkisi kaçınma güdüsünü harekete geçirerek mağdurun suçlu kişiyle ilişkiden uzaklaşmaya çalışmasına sebep olur (Asıc1, 2013). İkinci duygusal durum ise incinmeye sebep olan kişiye yönelik olan haklı öfkedir. Bu haklı öfke, suçlu kişinin zarara uğramasını arzu etmeye sebep olarak intikam alma güdüsünü ortaya çıkarır (McCullough, Exline ve Baumeister, 1998). 
Mağdur birey suçlu bireyi affedemediğini ifade ediyorsa olumsuz duyuşların ve güdülerin etkisi altında olduğu söylenebilmektedir. Bunun tersi şeklinde de eğer birey affetme davranışını gerçekleştirebiliyorsa bireyin iki olumsuz duyuş ve güdü etkisinden çıkmış olduğu ifade edilebilir (McCullough, 2000). Bu modelde affetme, hasara maruz kalan bireyin kaçınma ve intikam alma şeklindeki olumsuz güdülerinin, motivasyonlarının azalması, ilişkiyi olumlu yönden etkileyen güdülerinin, motivasyonlarının ise artması şeklinde tanımlanmaktadır (McCullough, Bellah, Killpatrick ve Johnson, 2001). Affetme bu modelde bir güdü olarak ele alınmamasına karşın, bireylerin hasara uğradıklarında, incindiklerinde meydana gelen güdülerin olumsuzdan olumluya doğru olan değişimine dayanmaktadır (Şamatac1, 2013).

\section{Piramit Modeli}

Duyuş ve güdü arasındaki ilişki üzerinden hareket ederek üç tür affetme olduğunu ifade eden Worthington (2005), bu affetme türlerine duygusal affetme, kararsal affetme ve kişilerarası affetme adını vermiştir. Duygusal affetme olumsuz duygular üzerinde değişiklik sağlama şeklinde ifade edilebilir. Olumlu duygular, incinme sonrasında mağdur bireyin yaşadığı olumsuz duyguların etkisini öncelikle sıfır hâline getirir sonrasında ise olumsuz duyguların varlığının azalmasını sağlar (Wade ve Worthington, 2003). Bu affetme türünde negatif duygular ile pozitif duyguların yer değiştirmesi esastır. Duygusal affetme, negatif duyguların incinen birey üzerindeki stresinin azalmasını sağlayarak birçok fizyolojik rahatsızlı̆̆ın önüne geçmede yardımcı olur (Adam Karduz, 2019). Kararsal affetme ise affetmenin bilişsel yönüne odaklanmaktadır. İncinen bireyin inciten bireye yönelik güdülerini ve davranışlarını olumsuzdan olumluya değiştirebileceklerine ilişkin düşünceler oluşması şeklinde tanımlanabilir (Worthington, 2003). Bu affetme türünde incinen birey hasarın sonucunda oluşan negatif duygulardan ve fikirlerden kurtulmaya niyetlenir (Satıcı, 2016). Bu niyetlenmede suçlu birey ile ilişki mağdur tarafından devam ettirilmek istenmiyorsa, intikam arzusundan vazgeçmek önemlidir. Karar temelli affetme birçok araştırmacı tarafından önemsenmiş ve çalışmalara dâhil edilmiştir (Baskin ve Enright, 2004). Kararsal affetmede incinen birey affetmeye niyetlendikten sonra affetmeyi deneyip denememek yahut affetme niyetini suçlu bireyle paylaşıp paylaşmamak noktasında özgürdür (Worthington, 2005). Son affetme türü olan kişiler arası affetme ise mağdur ile suçlu bireylerin ilişkiyi devam ettirmesinin istendiği durumlarda hatanın kapsamı, suçlu bireyin özellikleri, suçlu bireyin af dilemesi ve mağdur bireyin bu affı reddetmesi, incinen bireyin affetme 
üzerindeki fikirleri ve tavırları, suçlu bireyin kendini affetmesi benzeri süreçleri kapsamaktadır (Adam Karduz, 2019).

Worthington (1998), piramit modelinde affetmenin duyuşsal, davranışsal ve bilişsel boyutlarını da içerisine alarak beş aşamadan oluşan bir süreç öne sürmüştür. $\mathrm{Bu}$ süreç ise her basamağın ilk harfinin birleştirilmesiyle oluşturulmuş ve REACH ismini almıştır (Satıc1, 2016); recall the hurt (acıyı hatırlama), empathize with the person who hurt you (incitene yönelik empati geliştirme), altruistic gift of forgiveness (başkalarını düşünen bir hediye), commit to the emotional forgiveness (affetme için söz vermek), hold on to forgiveness (affetmeyi sürdürme) (Worthington, 2006).

İlk adım olan acıyı hatırlama noktasında birey, incinmeye sebep olan olayı zihninde canlandırarak tarafsız bir şekilde inceleme fırsatını bulur. $\mathrm{Bu}$ adım duygusal anlamda birey için zorlayıcı olabilmektedir. Bir sonraki adımda incinen kişi, olayı karşıdaki yani suçlu kişi açısından inceler, hissettiğini anlamaya çalışır ve inciten kişi ile empati kurarak pozitif duyguları deneyimler. Bu modelde affetmenin olabilmesi için ikinci adım yani empati geliştirme oldukça önemlidir (Worthington, 2006). Zarar veren kişiye karşı fedakâr davranma adımında ise incinen birey inciten bireye yönelik fikirlerinin değişmesi için de çaba göstererek diğerkâm bir tutumla yaklaşır (Asıcı, 2013). Bu adım incinen birey için zorlayıcı olsa da tam bir affetme için değerli bir noktada yer almaktadır (Worthington, 2006). Affeme için söz verme olan dördüncü adımda incinen bireyin inciten bireye affetmeyi bildirmesi beklenmemekle birlikte affettiğine yönelik bir söz vermesi istenir. Böylece son adım olan affetmeyi sürdürme noktasına ulaşılır, birey incindiğini unutmadan affetmeyi tercih ettiğini kendine sürekli bir şekilde hatırlatır (Adam Karduz, 2019). Bu adımda birey affetmeyi denemenin ve affetme davranışını sürdürmenin ruhsal iyi oluşuna katkısının farkına varır. Aynı zamanda incinmesine sebebiyet veren olayı zihninde sürekli tekrar ettirmesinin de affetmeye etkisine dikkat edilir (Worthington, 1998).

\section{Affetme Sürecinde Kişilik Özellikleri}

Affetme süreci suçlu bireyi, mağdur bireyi ve kimi zaman da incitici olaya şahit olan veya taraf tutan bireyleri farklı şekilde etkilemektedir (Worthington, 2005). Bu süreçte her birey farklı duygular içerisinde olsa dahi affetme sürecinin sonunda psikolojik yönden rahatlama yaşanır (Çardak, 2012). Affetme sürecinde kişilik özellikleri etkili olmakta ve bireylerin bağışlama davranışlarını kimi zaman kolaylaştırmakta kimi zamansa zorlaştırmaktadır. Benzer hatalı davranışlarda bazı 
bireylerin kolay affetmesinin bazı bireylerin ise intikam arzusu duymasının sebebi farklılaşan kişilik özellikleridir (Bugay, 2010).

Narsisizm, affetme ile değerlendirilen bir kişilik özelliğidir ve affetme ile kişilik özelliklerinin incelendiği araştırmalarda sıklıkla ele alınmıştır. Kişilik özelliklerinden biri olan narsisizm bireyin kendine hayranlık beslemesi, etrafındakilerden üstün olduğunu düşünmesi ve bu düşünceyle ilişkilerinde yarar sağlaması şeklinde tanımlanabilmektedir (Raskin ve Terry, 1998). Narsistik birey sebebi olduğu hatalı davranışta, oluşan hasarda sorumluluğunun olmadığını düşünür ve haklı olduğu yönünde savunmaya geçer. Bu durum da narsistik bireylerin affedicilik düzeylerinin düşük olduğunu düşündürmektedir (Taysi, 2007). Exline, Baumeister, Bushman, Campbell ve Finkel (2004)'in yaptı̆̆ eğilimini olumsuz yönde yordadığı sonucuna ulaşılmış, aynı zamanda erkeklerin daha fazla narsistik özelliklere sahip olduğu için kadınlardan daha az affettikleri ortaya çıkmıştır.

Brown (2004), affetme ve intikam alma arasındaki ilişkiyi incelediği araştırmada bu iki kavramın birbiriyle ilişkili aynı zamanda farklı olduğu sonucuna ulaşmıştır. Araştırma affetme eğiliminin yüksek olduğu bireylerde intikam arzusunun az olduğunu, affetme eğilimi düşük olan bireylerin ise intikam arzusu duyduğu sonucunu ortaya çıkarmıştır. Bununla birlikte affetme düzeyi düşük olan bireyler intikam arzusu duyan ve duymayan bireyler olarak iki koldan incelenmiş ve intikam arzusu duyan bireylerin narsisizm düzeylerinin yüksek olduğu gözlenmiştir (Taysi, 2007).

Kişilik özellikleri ve affetme arasındaki ilişkiyi araştırmalar genellikle yeniliğe açıklık, sorumluluk, dışadönüklük, uzlaşmacılık ve nörotizm olmak üzere kişiliğin beş boyutunu ölçen Beş Faktör Kişilik Modeli üzerinden ele almıştır (Kaya, 2015). Yapılan araştırmalar nörotizm ve affetme arasında negatif, uyumluluk ile arasında pozitif yönde anlamlı bir ilişki olduğunu ortaya çıkarmıştır (Walker ve Gorsuch, 2002). McCullough vd. (2001)'nin yaptığı araştırma ise intikamcılığın beş faktör kişilik modelinden nörotizm ile pozitif, uyumluluk ise de negatif yönde ilişkisi olduğunu göstermiştir. Beş Faktör Kişilik Modeli ile affetme arasındaki ilişkilerin incelendiği araştırmalar nörotizm (Exline vd., 2004) ve uyumluluk boyutları üzerinden tutarlı sonuçlar verirken (Walker ve Gorsuch, 2002), dişadönüklük yeniliğe açıklık ve sorumluluk boyutları üzerinde yapılan araştırmalar farklı sonuçlar ortaya çıkarmıştır (McCullough vd., 1998).

Dindarlık da bir kişilik özelliği kabul edilerek bazı araştırmalarda affetme ile arasındaki ilişki incelenmiştir. McCullough ve Worthington (1999), bu ilişki üzerine 
yapılan araştırmaların bulgularını derlemişler ve dindar bireylerin daha yüksek affetme eğilimine sahip olsalar da bu ikili arasındaki ilişkinin tahmin edildiğinin aksine güçlü olmadığını ifade etmişlerdir. $\mathrm{Bu}$ ifadenin temelinde ise dindar insanların din için önemli olması sebebiyle affetmeye değer verdikleri, affetme davranışını sergilemek için uğraştıkları düşüncesi yer almaktadır.

\section{Affetmeyi Kolaylaştıran ve Zorlaştıran Etmenler}

Affetme ve farklı değişkenler üzerine yapılan araştırmalar bazı değişkenlerin hasara sebep olan ilişki olaylarına verilen tepkiyi, affetme durumunu etkilediğini ortaya çıkarmıştır (Gauche ve Mullet, 2005; Warthington ve Wade, 1999). Bazı değişkenler affetmeyi kolaylaştırırken bazıları ise zorlaştırmaktadır (Scobie ve Scobie, 1998). Kolaylaştıran değişkenlerin bir kısmı empati, özür dileme, ilişkiye bağlanmayken zorlaştıran değişkenler zararın şiddeti, ruminasyonu şeklinde ele alınabilir (Freedman ve Enright, 1996).

İlişki hasarlarına sebebiyet vereni affetmeyi kolaylaştıran değişkenlerden biri olan özür dileme, hatanın suçlu birey tarafından dile dökülmüş hâlidir. Scobie ve Scobie (1998)'nin oluşturduğu Bütünleştirilmiş Affetme Modelinde özrün önemi detaylı olarak ele alınmıştır. Hasarın şiddeti arttıkça dilenen özrün samimiyeti mağdur tarafından değerlendirilir ve bu değerlendirme olumlu sonuçlanırsa affetme kolaylaşır. Gauche ve Mullet (2005)'in yaptığı araştırma ise psikolojik saldırıya uğrayan bireylerin (hakaret, aşağılama vb.) özür dileme davranışına ve niyet faktörüne fiziksel saldırıya uğramış bireylerden daha fazla önem verdiklerini ortaya çıkarmıştır. Suçlunun samimi bir şekilde özür dilemesi ve hataya yönelik duyduğu pişmanlığı içten bir şekilde ifade etmesi mağdur bireyin affetmesini kolaylaştırmaktadır (McCullough, 2000). Özür dilemek mağdurun suçluya yönelik pozitif duygular içerisine girmesine yardımcı olurken aynı zamanda suça sebep olan bireyin de rahatlamasını ve kendisini iyi hissetmesini sağlar (Çardak, 2012).

Özür dilemek ve pişmanlığın dilsel ifadesi mağdurun suçluya karşı duyduğu empatiyi artırır (Worthington ve Wade, 1999). Kişinin kendisini karşısındakinin yerine koyması, duygusal ve bilişsel anlamda içinde neler yaşadığını anlamaya çalışması şeklinde tanımlanan empati de affetmeyi kolaylaştıran değişkenlerden birisidir (McCullough vd., 1998). Worthington (1998)'un geliştirdiği Piramit Modelinde empatinin önemi üzerinde yoğunlaşılmıştır. Bununla birlikte affetmenin Süreç Modeli'nin Çalışma Evresi'nde de suçluya yönelik empati geliştirmenin affetmenin koşulu olduğu ifade edilmiştir (Gündüz, 2014). Mağdur bireyin suçlunun 
hatalı davranışı gerçekleştirirken hangi duygular ve koşullar içerisinde olduğunu anlaması affetmeyi kolaylaştıracaktır.

Affetme sürecinde kolaylaştırıcı etkiye sahip olduğu düşünülen bir diğer değişken de ilişkiye bağlanmadır. Webb, Call, Chickering, Colburn ve Heisler (2006)'in yaptığ çalışma güvenli bağlanan bireylerin affetme eğilimlerinin güvensiz bağlanan bireylerinkinden fazla olduğunu göstermiştir. Bununla birlikte ilişkide birbirlerine bağlılığ1 yüksek olan çiftler, bağlılığı düşük olan çiftlerden daha yüksek ilişki kalitesine ve uyumuna sahiplerdir. İlişki uyumunun yükselmesi affetmeyi kolaylaştırır. Bu sebeple birbirine bağlılığı yüksek olan çiftler daha kolay affetme kapasitesine sahiptir (Rusbult, Verette, Whitney, Slovik ve Lipkus, 1991). Ayn1 zamanda bağlanma kavramı bireyde ilişkiyi devam ettirme arzusuna sebep olur (Taysi, 2007). İlişkiye devam etme arzusu ise affetme davranışını beraberinde getirir. İlişkisine bağlı kişiler hatalı davranış sonucunda ilişkiyi devam ettirme arzusuyla affetme eğilimine girerler (Rusbult ve Buunk, 1993).

Bazı değişkenlerin artması affetme sürecini olumlu etkilerken bazı değişkenlerin artması da bu süreci olumsuz etkilemektedir (Kaya, 2015). Yukarıda bahsedildiği üzere empatinin, özür dilemenin ve bağlanmanın artması affetmeyi kolaylaştırmaktadır. Fakat zararın şiddetinin ve ruminasyon davranışının artması affetmeyi zorlaştırmaktadır (Satıcı, 2016). Yapılan araştırmalar zararın şiddetinin artması ile affetme arasındaki ilişkinin ters yönde olduğunu göstermiştir. Farklı bir ifadeyle zararın şiddeti arttıkça affetme eğilimi azalmaktadır (Boon ve Sulsky, 1997). Bununla birlikte zararın şiddetini ölçmek için nesnel bir yöntem mevcut değildir. Öznel bir yapı sergileyen zararın şiddeti kişiden kişiye farklılaşabilmektedir. Mağdur birey için zararın şiddeti çok yüksek değerlendirilirken suçlu birey için aynısı geçerli olmayabilmektedir. Bu farklılık taraflar arasında anlaşmazlığa sebep olabileceği gibi empati duygusunu azaltıp affetme sürecini zorlaştırabilmektedir (Çardak, 2012).

Beklenmedik anlarda meydana gelen, tekrarlayıc bir yapı sergileyen ve uyum bozucu davranışlara sebebiyet veren duyguyla yüklenmiş biliş şeklinde tanımlanan ruminasyon, affetmeyi zorlaştıran etmenlerden biridir (Kaya, 2015). Zararı ortaya çıkaran davranış sonucunda mağdurun ruminasyon yapması affetmekte zorlanmasına, ruminasyonu azaltmaya yönelik gösterilen çaba da intikam yahut kaçma arzusuna sebep olmaktadır (McCullough, 2000). İntikam arzusu içerisindeki bireyler suçlunun sebep olduğu hasarı ödetmek ve suçluya ders vermek yönünde tekrarlayan düşüncelere sahiplerdir. İntikamcı ve öfkeli ruminasyon ile affetme arasındaki ilişki negatif yönde anlamlı bir çizgi sergilemekte ve ruminasyonlar affetme davranışını zorlaştırmaktadır (McCullough vd., 2001). 
Yukarıda bahsedilen değişkenler affetme sürecini kimi zaman zorlaştırıp kimi zaman kolaylaştırsa da affetme davranışı mağdur bireyin kendi başına içsel bir şekilde ve kimsenin baskısı olmadan aldığı bir karardır.

\section{Affetmenin Faydaları}

Kin, öfke gibi olumsuz duyguların yerini olumlu duygulara bırakması, intikam fikirlerinin zihinden uzaklaştırılması şeklinde tanımlanabilen affetme, bireylerin sağlıklarını fizyolojik, zihinsel ve manevi yönden olumlu etkileyen bir süreçtir (Mameghani, 2017). Affetmenin psikolojik ve fizyolojik sağlığa etkisi birçok araştırmacının merak ederek çalışmalarında odaklandığı bir konu olmuştur (Lawler, Younger, Piferi, Jobe, Edmondson ve Jones, 2005; Toussaint vd., 2001; Witvliet, Ludwig ve Vonder Laan, 2001; Toussaint ve Webb, 2005). Toussaint vd. (2001)'nin yaptığı araştırmada kolay affedebilen bireylerin gösterdikleri hastalık belirtilerinin daha az olduğu ve affetmenin fizyolojik sağlığa pozitif yönde etkisi olduğu ortaya çıkarılmıştır. Bu araştırmanın tersi yönünde yapılan bir çalışmada ise Witvliet vd. (2001) affetmede zorluk yaşayan kişilerin içinde bulundukları negatif duygular sebebiyle stresin yüksek olduğu bir yaşam sürdügünü ve sürdürülen bu yaşamın fizyolojik sağlığı negatif yönde etkilediğini ifade etmişlerdir. Lawler vd. (2005)'nin yaptığı çalışma da affetmenin olumsuz duygular yerine yerleştirdiği olumlu duyguların bireylerin sağlığının iyileşmesini sağlayan değerli bir değişken olduğunu gözler önüne sermiştir.

Fizyolojik sağlığın yanında affetme zihinsel ve psikolojik sağlığı da olumlu yönde etkilemektedir (Satıcı, 2016). Affetme davranışını kolay gerçekleştirebilen bireyler kişiler arası ilişkilerde daha başarılıdır ve sosyal anlamda aldıkları destek yüksek olduğundan daha sağlıklı davranmakta ve zihinsel anlamda sağlıklarını da koruma altında tutabilmektedirler (Toussaint ve Webb, 2005). Affetme eğilimi yüksek olan bireyler kendini olumlu bir şekilde ifade edebilmektedir (Tüccar, 2015). Bu bireylerin günlük hayatlarında kurdukları sosyal ilişkilerden sağladıkları doyum daha yüksek olmaktadır (Gürbüz, 2016). Bununla birlikte affetme süreci incinen bireyin zarar veren bireye karşı oluşan negatif duygularla pozitif duyguların yer değiştirmesini içerdiğinden kişiler arası ilişkilerde yardımseverliğin yükselmesini sağlamaktadır (Satıc1, 2016).

Manevi yönden bakıldığında ise hemen hemen tüm dinler, inananlarının affetme yönünde ilerlemelerini istemekte ve bu yönde telkinlerde bulunmaktadırlar. $\mathrm{Bu}$ telkinler insanların kin tutmamaları, intikam düşünceleri içerisinde bulunmamaları gerektiği öğütlerini de barındırmaktadır. Bu sebeple affeden birey dinin verdiği 
öğütleri gerçekleştirdiği ve dinine uygun hareket ettiği yönünde fikirlere sahip olarak manevi huzur hissetmektedir (Van Tongeren, Green, Hook, Davis, Davis ve Ramos, 2015).

Yapılan araştırmalar değerlendirildiğinde affetmenin fiziksel, psikolojik, zihinsel, manevi yönde incinen bireye fayda sağladığı anlaşılmaktadır.

\section{Affetme ile İlgili Yapılan Çalışmalar}

Braithwaite vd. (2016) kişilik özelliklerinin ve affetme düzeylerinin bir-iki yıl arasında süren oturmuş romantik ilişkilerdeki doyumu ölçmede rolünü incelediği araştırma affetme düzeyinin ilişki doyumu ile doğrudan pozitif yönde ve affetme düzeyi ile kişilik özelliklerinden nevrotiklik arasında negatif yönde bir ilişki olduğunu göstermiştir.

McCullough vd. (1998) yaptıkları araştırmada sosyal yakınlığın zarar veren partnerin özür dilemesinde ve zarar gören partnerin ise kendisini inciten partnerine yönelik empati duymasında aracı role sahip olduğu ve sosyal yakınlığın bireylerin affetme düzeylerini artırdı̆̆ı sonucuna ulaşmışlardır.

Tse ve Yip (2009) kişilerarası uyumun psikolojik iyi oluş ve affetme üzerinde aracı rolü olduğunu ve affetmenin psikolojik iyi oluş ve kişilerarası uyumu artırdı̆̆ını ortaya çıkarmıştır. Van Tongeren vd. (2015) ise yaptıkları araştırmada eşlerine yönelik affetme eğilimleri yüksek olan bireylerin hayata yönelik algıladıkları anlamın daha yüksek olduğu ve affetme eğilimini artıran en önemli faktörün de eşlerin karşılıklı olarak hatalarını kabul edebilme seviyeleri olduğu sonucuna ulaşmıştır.

Affetmenin sosyal ilişkilerin sürdürülmesinde, gereksiz anlaşmazlıkların önlenmesinde ve kişinin hayatında ilerlemeye devam etmesinde önemli bir rol oynadığı görüşünü savunan Noreen, Bierman ve Maclead (2014)'in yaptıkları araştırma; affedilen olayların kolay unutulduğunu, affedilmeyen olayların ise unutulmasında bireylerin zorlandığını ortaya çıkarmıştır.

Affetme üzerine yapılmış deneysel çalışmalar uygulanan programın anksiyete ve depresyon düzeylerini azaltırken affetme ve umut düzeylerini artırdığını (Freedman ve Enright, 1996) ve affetme kavramının benimsenmesini kolaylaştırdığı, varoluşsal iyi oluş düzeyini ve benlik saygısını yükselttiğini (Rye ve Pargament, 2002) ortaya çıkarmıştır.

Affetme, mutluluk ve tolerans düzeylerini Türkiye ve İran'daki üniversite öğrencileri üzerinden karşılaştıran araştırmada Mameghani (2017) affetme düzeylerinin bu iki kültüre göre farklılaşmadığını tespit etmiştir. Kaya ve Orçan (2019) empatik eğilimin bireylerin affetme ve yaşam doyumu düzeyleri üzerinde etkisinin olduğunu ve 
mutluluğun, empatik eğilim, yaşam doyumu ve affetme düzeylerinde aracı rolü olduğunu ortaya çıkarmıştır. Topbaşoğlu Altan ve Çivitçi (2020) ise gerçekleştirdiği çalışmada öfke ve yaşam doyumu arasındaki ilişkide kendini affetme ve durumu affetme alt boyutlarının düzenleyici rolünün bulunmadığını, başkalarını affetme alt boyutunun ise düzenleyici rol üstlendiğini ortaya çıkarmıştır.

Halisdemir (2013), psikolojik iyi oluş ile affetme düzeyi arasında pozitif yönde bir ilişkiyi vurgularken kendini kabul ve yaşam amacı düzeyinin en yüksek yordayıcısının kendini affetme düzeyi olduğunu ortaya çıkarmıştır. Olumlu kişiler arası yönelim yüksek affetme puanını beraberinde getirmekte (Arslan, 2019) ve affetme sosyal bağlılık düzeyini yordamaktadır (Satıcı, 2016).

Affetmeme düzeyini düşürmeden affetme eğilimini artırmanın mümkün olmadığını fark eden araştırmacılar deneysel çalışmalar yaparak affetmeme düzeyini azaltmaya çalışmışlardır. Bu noktada yapılan deneysel çalışmalarda uygulanan programların kişilik özelliklerinden deneyime açıklık, dışadönüklük, sorumluluk, uyumluluk üzerinde artırıcı bir etki sağlarken; kişilik özelliklerinin nevrotiklik puanlarının azalmasını sağladığı (Adam Karduz, 2019), affetme eğilimini artırdığı (Asıcı, 2018; Akbulut, 2018; Çolak, 2014; Bugay ve Demir, 2012), belirsizliğe tahammülsüzlük ve öfke düzeylerini azalttığı (Çardak, 2012) gözlenmiştir.

Özetlenecek olursa affetme üzerinde yapılan araştırmalar; affetmenin ilişki doyumu (Braithwaite vd., 2016; Keleş, 2018; Tunç, 2015), kişilik özellikleri (Walker ve Gorsuch, 2002; Adam Karduz, 2019), sürekli öfke durumu (Aslan, 2016; Besim, 2017; Kaya, 2015), psikolojik iyi oluş (Tse ve Yip, 2009; Çardak, 2012; Yaşar, 2015; Şahin, 2013; Dolunay Cuğ, 2015), bağlanma stilleri (Seyfi, 2017; Gürbüz, 2016; Ceyhan, 2019; Yaman Akpınar, 2019), yaşam doyumu (Küçüker, 2016), empati (Bayar, 2015; Gümüşçağlayan, 2018), mutluluk (Mameghani, 2017; Kaya ve Orçan, 2019) vb. değişkenler ile arasındaki ilişki üzerinde yoğunlaşmıştır.

\section{Sonuç}

Bu çalışmada, affetme konusu kuramsal olarak ele alınmıştır. Çalışmaya konu olan affetme kavramı kabul gören tek bir tanıma sahip değildir. Fakat mevcut tanımların birtakım ortak noktaları vardır. İnsanın ihtiyaç duyduğu sosyal ilişkilerin kimi zaman kötü sonuçlanması sebebiyle birey hasar görebilir. Oluşan bu hasar beraberinde öfke, kırgınlık, kin benzeri negatif duyguları getirir ve affetme, incinen bireyin negatif duyguların farkına vararak bu duygulardan bilinçli bir çaba ile sıyrılması ve hasara sebebiyet veren kişi için olumlu duygular yaşamak yolunda uğraş sarf etmesiyle oluşur. Olumsuz duygulara sebep olan tüm olaylar affetmeyi 
gerektirmeyebilir. Kimi zamanlarda meydana gelen küçük ihlaller özür ile geride bırakılabilir. Fakat bazı negatif deneyimler incinen bireyin benlik saygısını azaltıcı ve zarar verici etkiler bırakabilir. Bu gibi durumlarda affetme davranışı hasara sebebiyet veren kişinin hasara yönelik sorumluluğunun ortadan kalktığını, mağdurun bu deneyimi tamamen unuttuğunu göstermemektedir (Scobie ve Scobie, 1998).

Suçlu kişiye yönelik empatik bir bakış açısıyla yaklaşmak, onun da hata yapma eğilimine sahip bir varlık olduğunu fark etmeye çalışmak mağdur kişinin affetme davranışını yerine getirmek için uygulaması gereken adımlardır (Enright ve The Human Development Study Group, 1996). Mağdur birey affetme davranışını suçlu olan kişi için değil aksine kendisi için gerçekleştirmektedir. Çünkü incitici davranışın sebep olduğu hasar mağdur bireyin gelecekte yaşayacağı ilişkilerde benzer bir zarara uğramamak için mesafeli davranışlar geliştirme ihtimalini doğurur. Affetme davranışı mağdur bireyin incitici davranışa yönelik yükünü alarak bu ihtimalin gerçekleşme olasılığını düşürecektir (Kaya, 2015). Başka bir ifade ile affetmek mağdur bireyin ileride yaşayacağ 1 ilişkilerin kalitesini artıracak ve psikolojik bir iyileşme sağlayacaktır (Gümüşçağlayan, 2018). Affetme, kişiler arası ilişkilerin sürdürülmesini ve hasarın onarılmasını kolaylaştıran hem affediciye hem affedilene olumsuz etkiden ve geçmişin zarar verici mirasından arındırılmış yeni bir başlangıç sunan değerli bir stratejidir (Scobie ve Scobie, 1998).

Affetme, davranış olarak kökeni eskilere dayanan, kavramsal olarak ise başlangıçta dini düzlem üzerinden ele alınan, geçtiğimiz kırk yılda psikoloji alanyazınına giren ve son yıllarda da üzerindeki ilginin yükselişe geçtiği bir kavramdır (McCullough, Worthington ve Rachal, 1997).

Affetme üzerine hazırlanmış bu çalışma, kişinin kendi hatalarıyla yüzleşmesinin sağlandığı kendini affetme, kontrol dişında meydana gelen olayların oluşturduğu olumsuz duyguların azalmasının sağlandığı durumu affetme ve incindiği ilişkide karşısındaki kişinin davranışını anlamayı sağlayan başkalarını affetme kavramlarını ele almıştır. Bununla birlikte çalışmada; affetmeye yönelik farklı kuramcılar tarafından oluşturulmuş modeller, empati, özür dileme, ilişkiye bağlanma gibi affetmeyi kolaylaştıran ve zararın şiddeti, ruminasyon gibi affetmeyi zorlaştıran etmenler de ele alınırken affetme ve kişilik özellikleri arasındaki ilişkilere, affetmenin sağladığı faydalara da yer verilmiştir. Çalışma, affetme ile ilgili var olan araştırmaların ulaştığı sonuçları içerisine alarak, affetme kavramına ilişkin genel bir fotoğraf sunmuştur. Bu bağlamda hazırlanan çalışmanın affetme kavramının psikolojik iyileşme üzerindeki önemini hatırlatıcı olacağı ve alanyazına katkı sağlayacağı düşünülmüştür. Sonuç olarak affetme toplumsal bir varlık olan insanın 
hem kendisiyle hem de diğerleriyle kuracağ ilişkilerde kendini göstermekte olup kişinin ruh sağlığını korumada ve kişilerarası ilişkileri geliştirmede önemli bir yere sahiptir.

\section{Kaynakça}

Adam Karduz, F.F. (2019). Affetme eğilimi kazandırmaya yönelik psikoeğitim programının affetme eğilimi kazandırma ve beş faktör kişilik özellikleri üzerindeki etkisi (Yayımlanmamış doktora tezi). Sakarya Üniversitesi, Sakarya.

Akbulut, Z. (2018). İmago yaklaşımına dayah grupla psikolojik danışma uygulamalarının evli çiftlerin affetme ve mutluluk düzeyine etkisi (Yayımlanmamış yüksek lisans tezi). Sabahattin Zaim Üniversitesi, İstanbul.

Akgün, C. (2016). Affetmenin koşulu: Utanmak ve söz vermek. Psikeart, 47, 6-11.

Arslan, S. (2019). Öğretmen adaylarında kişilerarası tarz, affetme ve evlilik tutumu arasındaki iliş̧kinin incelenmesi (Yayımlanmamış yüksek lisans tezi). Uludă̆ Üniversitesi, Bursa.

Asıcı, E. (2019). Çocuk ve ergenlere yönelik affetme müdahaleleri: Sistematik gözden geçirme. Psikoloji Çalışmaları, 39 (2), 429-457.

Asıcı, E. (2013). Öğretmen adaylarının affetme özelliklerinin öz-duyarlık ve benlik saygısı açısından incelenmesi (Yayımlanmamış yüksek lisans tezi). Dokuz Eylül Üniversitesi, İzmir.

Asıcl, E. (2018). Affetme odaklı grup rehberliğinin ergenlerin saldırganlık ve öznel iyi oluşları üzerindeki etkisi (Yayımlanmamış doktora tezi). Dokuz Eylül Üniversitesi, İzmir.

Aslan, G. A. (2016). Üniversite öğrencilerinin affetme davranışları, yaşam doyumları ve sürekli öfke düzeyleri arasındaki ilişkinin incelenmesi (Yayımlanmamış yüksek lisans tezi). Gazi Üniversitesi, Ankara.

Baskin, T.W. ve Enright, R.D. (2004). Intervention studies of forgiveness: A metaanalysis. Journal of Counseling and Development, 82, 79-90.

Baumeister, R.E., Exline, J.J. ve Sommer, K.L. (1998). The victim role, grudge theory, and two dimensions of forgiveness. E.L.Worthington (Ed.), Dimensions of forgiveness: Psychological research and theological speculations (s.79-107). Pennsylvania: Templeton Foundation Press.

Bayar, Ö. (2015). Romantik ilişkilerde aldatma ve affetme: Empatinin rolü. (Yayımlanmamış yüksek lisans tezi). Üsküdar Üniversitesi, İstanbul. 
Besim, G. (2017). Üniversite öğrencilerinde affetme, bitirilmemiş işler ve öfke (Yayımlanmamış yüksek lisans tezi). Hacettepe Üniversitesi, Ankara.

Boon, S. ve Sulsky, L. (1997). Attributions of blame and forgiveness in romantic relationships: A policy-copturing study. Journal of Social Behavior and Personality, 12(1), 19-45.

Bowman, I.G. (2003). Exploring the retrospective experience of self forgiveness in psychotheraphy (Yayımlanmamış doktora tezi). University of Pretoria, South Africa.

Braithwaite, S. R., Mitchell, C. M., Selby, E. A. ve Fincham, F. D. (2016). Trait forgiveness and enduring vulnerabilities: Nevroticism and catastrophizing influence relationship satisfaction via less forgiveness. Personality and Individual Differences (94), 237- 246.

Brown, R.P. (2004). Vengeance is mine: Narsisizm, vengeance and the tendency to forgive. Journal of Research in Personality, 38, 576-584.

Bugay, A. (2010). Kendini affetmeyi yordayan sosyo-bilişsel, duygusal, davranışsal faktörlerin incelenmesi (Yayımlanmamış doktora tezi). Orta Doğu Teknik Üniversitesi, Ankara.

Bugay, A. ve Demir, A. (2011). Hataya ilişkin özelliklerin başkalarını affetmeyi yordaması. Türk Psikolojik Danışma ve Rehberlik Dergisi (35), 8-17.

Bugay, A. ve Demir, A. (2012). Affetme artırılabilinir mi?: Affetmeyi geliştirme grubu. Türk Psikolojik Danışma ve Rehberlik Dergisi, 4 (37), 96-106.

Ceyhan, C.H. (2019). Evli bireylerin bağlanma stilleri ve psikolojik ihtiyaçları ile affetme düzeyleri arasındaki ilişkinin incelenmesi (Yayımlanmamış yüksek lisans tezi). Necmettin Erbakan Üniversitesi, Konya.

Çardak, M. (2012). Affetme yönelimli psiko-eğitim programının affetme eğilimi, belirsizliğe tahammülsüzlük, psikolojik iyi oluş, sürekli kaygi ve öfke üzerindeki etkisinin incelenmesi (Yayımlanmamış doktora tezi). Sakarya Üniversitesi, Sakarya.

Çolak, T.S. (2014). Affetme esnekliği kazandırmada logoterapi yönelimli grupla psikolojik danışmanın etkililiği (Yayımlanmamış doktora tezi). Sakarya Üniversitesi, Sakarya.

Dolunay Cuğ, F. (2015). Öznel iyi oluşun yordayıcıları olarak kendini affetme, özduyarlılık, öznel yaşam enerjisi ve mutluluğa yönelim (Yayımlanmamış doktora tezi). Orta Doğu Teknik Üniversitesi, Ankara. 
Enright, R. D. (1996). Counseling within the forgiveness triad: On forgiving, receiving forgiveness, and self forgiveness. Counseling and Values, 40 (2), 107-126.

Enright, R.D. (2001). Forgiveness is a choice: a step by step process for resolving anger and restoring hope. Washington: American Psychological Association.

Enright, R.D. ve Coyle, C.T. (1998). Researching the process model of forgiveness within psychological interventions. E.L. Worthington içinde, Dimensins of forgiveness: Psychological research and theological perspectives (s.139-161). Pennsylvania: Templeton Foundation Press.

Enright, R.D. ve The Human Development Study Group (1996). Counseling within the forgiveness friad: On forgiving, receiving, forgiveness and self-forgiveness. Counseling and Values, 4, 107-126.

Exline, J.J., Baumeister, R.F., Bushman, B.J., Campbell, W.K. ve Finkel, E.J. (2004). Too proud to let go: Narcissistic entitlement as a borrier to forgiveness. Journal of Personality and Social Psychology, 87 (6), 894-912.

Fincham, F. D. (2000). The kiss of the porcupines: From attributing responsibility to forgiving. Personal Relationships, 7, 1-23.

Freedman, S.R, ve Enright, R.D. (1996). Forgiveness as an intervention goal with incest survivors. Journal of Consulting and Clinical Psychology, 64, 983-992.

Gauche, M. ve Mullet, E. (2005). Do we forgive physical aggression in the same way that we forgive psychological aggression? Aggressive Behavior, 31 (6), 559-570.

Goldgarb, J.C. (2005). The emergence, expression and integration of forgiveness: $A$ psychodynamic explaration and case study (Yayımlanmamış doktora tezi). Alliant International University, San Diego.

Gümüşçağlayan, G. (2018). Psikolojik danışman adaylarının affetme düzeyleri ile psikolojik belirtileri arasındaki ilişkide empatinin aracılık rolü (Yayımlanmamış yüksek lisans tezi). Mehmet Akif Ersoy Üniversitesi, Burdur.

Gündüz, Ö. (2014). Üniversite Öğrencilerinde Affetmeyi Yordayan Değişkenlerin Belirlenmesi. Yayımlanmamış Yüksek Lisans Tezi, Ankara Üniversitesi, Ankara.

Gürbüz, E. (2016). Evlilik içinde aldatılan bireylerin affetmelerini yordamada bağlanma stilleri ve psikolojik să̆lamlı̆̆ın rolü (Yayımlanmamış yüksek lisans tezi). Bahçeşehir Üniversitesi, İstanbul

Hall, J.H. ve Fincham, F.D. (2005). Self-forgiveness: The stepchild of forgiveness research. Journal of Social and Clinical Psychology, 24 (5), 621-637. 
Hall, J.H. ve Fincham, F.D. (2008). The temporal course of self-forgiveness. Journal of Social and Clinical Psychology, 27 (2), 174-180.

Halisdemir, D. (2013). Üniversite öğrencilerinin psikolojik iyi oluşları, kendini affetme düzeyleri ve geçmişe yönelik anne kabul-red algıları arasındaki ilişkiler (Yayımlanmamış yüksek lisans tezi). Gazi Üniversitesi, Ankara.

Hargrave, T. (2001). Forgiving the devil: Coming to terms with damaged relationships. Phoenix: Tucker \& Theisen.

Hargrave, T. ve Sells, J.N. (1997). The development of a forgiveness scale. Journal of Mariatal and Family Theraphy, 23, 41-62.

Hefferon, K. ve Boniwell, I. (2014). Pozitif psikoloji kuram, araştırma ve uygulamalar. Ankara: Nobel Akademik Yayıncılık.

Hortwitz, L. (2005). The capacity to forgive: Intrapsychic and developmental perspectives. Journal of the American Psychoanalytic Association. 53 (2), 485-511.

Kaya, F. (2015). Üniversite öğrencilerinin affetme ve mükemmeliyetçilik düzeyleri arasındaki ilişki: duygusal zekânın aracı rolü (Yayımlanmamış yüksek lisans tezi). Atatürk Üniversitesi, Erzurum.

Kaya, Ö. S. ve Orçan, F. (2019). Mutluluğun empati, affetme ve yaşam doyumu arasındaki aracı rolü: Bir yol analizi. Bolu Abant İzet Baysal Üniversitesi Ĕ̆gitim Fakültesi Dergisi, 19 (2), 540-554.

Keleş, A. (2018). Evlilik kalitesi ile affetme, ikili ilişkilerde güven ve mizah tarzları arasındaki ilişkilerin incelenmesi (Yayımlanmamış yüksek lisans tezi). Mehmet Akif Ersoy Üniversitesi, Burdur.

Küçüker, D. (2016). Affetme, affetmeme, bilişsel esneklik, duygu düzenleme ve yaşam doyumu arasındaki ilişkilerin incelenmesi (Yayımlanmamış yüksek lisans tezi). Pamukkale Üniversitesi, Denizli.

Lawler, K.A., Younger, J.W., Piferi, R.L., Jobe, R.L., Edmondson, K.A. ve Jones, W.H. (2005). The unique effects of forgiveness on health: An exploration of pathways. Journal of Behavioral Medicine, 28 (2), 157-167.

Mameghani, S.S. (2017). Türkiye ve Iran'daki üniversite öğrencilerinin affetme, tolerans ve mutluluk düzeylerinin karşılaştırılması (Yayımlanmamış doktora tezi). 19 Mayıs Üniversitesi, Samsun. 
McCullough, M.E., Bellah, C.G., Kilpatrick, S.D. ve Johnson, J.L. (2001). Vegnefulness: Relationships with forgiveness, rumination, well-being and the big five. Personality and Social Psychology, 27 (5), 601-610.

McCullough, M.E., Exline, J.J. ve Baumeister, R.F. (1998). An annotated bibliography of research on forgiveness and related concepts, E.L. Worthington içinde, Dimensions of forgiveness: Psychological research and theological perspectives (s. 193317). Pennsylvania: Templeton Foundation Press.

McCullough, M.E. (2000). Forgiveness as human stenght: Theory, measurement and links to well-being. Journal of Social and Clinical Psychology, 19 (1), 43-45.

McCullough, M.E. (2001). Forgiveness: Who does it and how do they do it? Current Directions in Psychological Science, 10 (6), 194-197.

McCullough, M.E. ve Worthington, E.L. (1999). Religion and the forgiving personality. Journal of Personality, 67 (6), 1141-1164.

McCullough, M. E., Worthington, E. L. ve Rachal, K. C. (1997). Interpersonal forgiving in close relationships. Journal of Personality and Social Psychology, 73, 321-336.

Murdock, N.L. (2012). Psikolojik damışma ve psikoterapi kuramları. (F. Akkoyun, Çev.). Ankara: Nobel Yayınevi.

Noreen, S., Bierman, R. N. ve MacLeod, M. D. (2014). Forgiving you is hard, but forgetting seems easy: Can forgiveness facilitate forgetting? Psychological Science, $25,1295-1302$.

Oral, T. (2016). Üniversite öğrencilerinin affetme düzeylerinin öz anlayıs, kişiler arası hataya ilişkin ruminasyon ve kişilik özellikleri açısından incelenmesi (Yayımlanmamış doktora tezi). Necmettin Erbakan Üniversitesi, Konya.

Raskin, R. ve Terry, H. (1998). A principal components analysis of the narcissistic personality inventory and further evidence of its construct validity. Journal of Personality and Social Psychology, 54 (5), 890-902.

Rusbult, C.E. ve Buunk, B.P. (1993). Commitment process in close relationships: An interdependence analysis. Journal of Social and Personal Relationships, 10 (2), 175204.

Rusbult, C.E., Verette, J., Whitney, G.A., Slovik, L.F. ve Lipkus, I. (1991). Accommodation processes in close relationships: Theory and preliminary empirical evidence. Journal of Personality and Social Psychology, 60, 53-78. 
Rye, M.S. ve Pargament, K.I. (2002). Forgiveness and romantic relationships in college: Can it heal the wounded heart? Journal of Clinical Psychology, 58 (4), 419441.

Satıcı, S.A. (2016). Üniversite öğrencilerinin affetme, intikam, sosyal bağhllık ve öznel iyi oluşları: farklı yapısal modellerin denenmesi üzerine bir araştırma (Yayımlanmamış Doktora Tezi). Anadolu Üniversitesi, Eskişehir.

Scobie, E.D. ve Scobie, G.E.W. (1998). Domoging events: The perceived need for forgiveness. Journal of the Theory of Social Behaviour, 28, 373-401.

Sells, J.N. ve Hargrave, T. (1998). Forgiveness: A review of the theoretical and empirical literature. Journal of Family Theraphy, 20 (2), 21-36.

Seyfi, S. (2017). Evli bireylerin aldatma eğilimleri ve affetme düzeylerinin bağlanma stillerine göre incelenmesi (Yayımlanmamış yüksek lisans tezi). Çukurova Üniversitesi, Sosyal Bilimler Enstitüsü, Adana.

Şahin, M. (2013). Affedicilik ile psikolojik iyi olma arasındaki ilişkinin çeşitli değişkenler açısından incelenmesi (Yayımlanmamış yüksek lisans tezi). Sakarya Üniversitesi, Eğitim Bilimleri Enstitüsü, Sakarya.

Şamatacı, G. (2013). Romantik ilişkilerde affetme: Transaksiyonel analiz ego durumları açısından bir inceleme (Yayımlanmamış yüksek lisans tezi). Marmara Üniversitesi, İstanbul.

Taysi, E. (2007). İkili ilişkilerde bă̆ışlama: İlişki kalitesi ve yüklemelerin rolü (Yayımlanmamış doktora tezi). Ankara Üniversitesi, Ankara.

Thompson, L. Y., Snyder, C. R., Hoffman, L., Michael, S. T., Rasmussen, H. N., ve Billings, L. S. (2005). Dispositional forgiveness of self, others and situations. Journal of Personality, 73, 313-359.

Topbaşoğlu Altan, T. ve Çivitçi, A. (2017). Öfke ve yaşam doyumu arasındaki ilişkide affetmenin düzenleyici rolü. Mehmet Akif Ersoy Üniversitesi Sosyal Bilimler Enstitüsü Dergisi, 18 (9), 308-327.

Toussaint, L. ve Webb, J.R. (2005). Theoretical and empirical connections between forgiveness, mental health and well-being, E.L. Worthington içinden, Handbook of forgiveness (s. 349-362). New York: Routledge.

Toussaint, L., Williams, D.R., Musick, M.A. ve Everson, S.A. (2001). Forgiveness and health: Age differences in a US probability sample. Journal of Adult Development, 8 (4), 249-257. 
Tunç, E. (2015). Üniversite öğrencilerinin romantik ilişkilerinde yaşadıkları istismar ile ilişki doyumu, affetme ve kıskançlık düzeylerinin arasındaki ilişkinin incelenmesi (Yayımlanmamış yüksek lisans tezi). Abant İzzet Baysal Üniversitesi, Bolu.

Tüccar, E. (2015). Engellilerde affetme ve yaşam kalite düzeylerinin farklı değişkenlere göre incelenmesi (Yayımlanmamış yüksek lisans tezi). Nişantaşı Üniversitesi, İstanbul.

Tse, W. S. ve Yip, T. H. (2009). Relationship among dispositional forgiveness of others, interpersonal adjustmentand psychological well-being: Implication for interpersonal theory of depression. Personality and Individual Differences, 46, 365368.

Van Tongeren, D.R., Green, J.D., Hook, J.N., Davis, D.E., Davis, J.L. ve Romos, M. (2015). Forgiveness increases meaning in life. Social Psychological and Personality Science, 6 (1), 47-55.

Wade, N.G. ve Worthington, E.L. (2003). Overcoming interpersonal offenses: Is forgiveness the only way to deal with unforgiveness? Journal of Counseling and Development, 81, 343-353.

Walker, D.F. ve Gorsuch, R.L. (2002). Forgiveness within the big five personality model. Personality and Individual Differences, 32, 1127-1137.

Webb, M., Call, S., Chickering, S.A., Colburn, T.A. ve Heisler, D. (2006). Dispositional forgiveness and adult attachment styles. The Journal of Social Psychology, 146 (4), 509-512.

Witvliet, C., Ludwig, T.E. ve Vander Laan, K.L. (2001). Granting forgiveness or harboring grudgos: Implications for emotion, physiology and health. Psychological Science, 12 (2), 117-123.

Worthington, E.L. (1998). An Emphaty-humility-commitment model of forgiveness applied within family dyads. Journal of Family Therapy. 20 (1), 59-76.

Worthington, E.L. (2006). Forgiveness and reconciliation: Theory on application. New York: Routledge.

Worthington, E.L. (2005). Initial questions about the art and science of forgiving, E.L. Worthington içinde, Handbook of forgiveness (s. 1-14). New York: Routledge.

Worthington, E.L. ve Wade, N.G. (1999). The psychology of unforgiveness and forgiveness and implications for clinical practice. Journal of Social and Clinical Psychology, 18 (4), 385-418. 
International Journal of Current Approaches in Language, Education and Social Sciences

Yaman Akpınar, T. (2019). Bağlanma stilleri ve affetme düzeyinin evlilik uyumuna etkisi. (Yayımlanmamış yüksek lisans tezi). Selçuk Üniversitesi, Konya.

Yaşar, K. (2015). Eğitim fakültesi öğrencilerinin öznel iyi oluş düzeyleri ile psikolojik sağlamlı ve affetme düzeyleri arasındaki ilişki (Yayımlanmamış yüksek lisans tezi). Uludağ Üniversitesi, Bursa. 